\title{
Consequences of micro-system setting on different component of learning disability
}

\author{
Nigam Rani and Sheela Sangwan
}

Received: 18.04.2020; Revised: 05.10.2020; Accepted: 19.10.2020

See end of the paper for authors' affiliations Nigam Rani

Department of Human

Development and Family

Studies, I.C. College of Home

Science, C.C.S. Haryana

Agricultural University, Hisar

(Haryana) India

Email : nigam.rani87@gmail.

com
ABSTRACT : Learning disability refers to a neurological disorder. This disability affects childs' thinking and learning process. It affects childs' ability to learn and engage in activities, his or her self-esteem and ability to evaluate difficult situation and make choices. This can lead to trouble with learning new skills and information. Families of learning disabled child also suffer a lot. They find it difficult to deal with the situation. Present study was carried out in Haryana state on learning disabled boys. Hisar district from Haryana state was selected purposively. From Hisar district Block I was selected on random basis. Hisar city was also selected purposively for urban sample. From Block I five villages named Kaimari, Mangali, Harikot, Daya and Singran were selected randomly. A sample of 60 boys (30 from urban and 30 from rural) with learning disability was selected for the study. Learning disability among boys of 10-12 years age group was taken dependent variable. Indian Adaptation of Stanford - Binet (1971) was administered for diagnosis of learning disability among boys of 10-12 years of age. It has the following components: Language, Mathematics, and Creativity. Different micro system variables were considered as independent variable. Results discovered that majority of the respondents were found in below average category for language and mathematics components of learning disability. Result further found that most of the boys were found in above average category in creativity component of learning disability.

KEY WORDS: Learning disability, Micro-system variables, Components of learning disability

- HOW TO CITE THIS PAPER : Rani, Nigam and Sangwan, Sheela (2020). Consequences of microsystem setting on different component of learning disability. Asian J. Home Sci., 15 (2) : 185-191, DOI: 10.15740/HAS/AJHS/15.2/185-191. Copyright@ 2020: Hind Agri-Horticultural Society. 